原 著

\title{
後鼻漏化学成分の定量による検討
}

広島大学医学部耳鼻咽喉科学教室

$\begin{array}{lllllr}\text { 平田したう } & \text { 立川 } & \text { 隆治 } & \text { 益田 } & \text { 慎 } \\ \text { 竹野幸夫 } & \text { 長田 } & \text { 理 加 } & \text { 川本 } & \text { 浩子 } \\ \text { 堀部 よし恵 } & \text { 夜 陣 } & \text { 紘 治 } & & \end{array}$

\section{QUANTITATIVE ANALYSIS OF SIALIC ACID, L-FUCOSE, ELASTASE AND ALBUMIN IN THE POST NASAL DRIP OF PATIENTS WITH CHRONIC SINUSITIS}

\author{
Shitau Hirata, M.D., Takaharu Tatsukawa, M.D., Shin Masuda,M.D., \\ Sachio Takeno, M.D., Rika Osada,M.D., Hiroko Kawamoto, M.D., \\ Yoshie Horibe, M.D. and Koji Yajin, M.D.
}

Department of Otolaryngology, Hiroshima University School of Medicine

\begin{abstract}
Quantitative analysis of sialic acid, L-fucose, elastase and albumin in the post-nasal drip of patients with chronic sinusitis was performed. Sixty-five cases of post-nasal drip were collected from patients with chronic sinusitis, aged 16 88 years old. The patients were classified into two groups: i.e.nonallergic group ( $n=58$, without allergic rhinitis), and allergic rhinitis group ( $n=7$, with allergic rhinitis). Additionally four cases of post-nasal drip obtained from patients with acute sinusitis were examined.

The mean concentration of sialic acid in the post-nasal drip from allergic rhinitis group $(625-1850 \mu \mathrm{g} /$ $\mathrm{ml}$ ) was significantly lower than that of acute sinsitis group $(85-7094 \mu \mathrm{g} / \mathrm{ml})$. However, there was no significant difference in the mean concentration of sialic acid in the post-nasal drip between acute sinusitis and nonallergic group $(85-7094 \mu \mathrm{g} / \mathrm{ml})$. The mean concentration of L-fucose in the post-nasal drip showed no significant differences in the groups of acute sinusitis $(359-567 \mu \mathrm{g} / \mathrm{ml})$, nonallergic group (33$33312 \mu \mathrm{g} / \mathrm{ml})$ and allergic group $(166-2842 \mu \mathrm{g} / \mathrm{ml})$. The concentration ratios of sialic acid to fucose (S/ F) in the post-nasal drip either nonallergic or allergic group were significantly lower than that of acute sinusitis. The activity of elastase in the post-nasal drip from nonallergic group was significantly lower than that of acute sinusitis. The mean concentration of albumin in the post-nasal drip in three groups showed statistically no significant difference.

In 8 cases with nonallergic group and in 4 cases with allergic group the analysis of the $\mathrm{S} / \mathrm{F}$ ratio was performed before and after the administration of antibiotics. In five cases with nonallergic group of which the treatment were effective, the $\mathrm{S} / \mathrm{F}$ ratio was lowerd significantly after the drug administration. These findings suggest that the $\mathrm{S} / \mathrm{F}$ ratio may be an impotant index for understanding the condition of chronic sinusitis.
\end{abstract}

Key words : 慢性副鼻腔炎, 後鼻漏, シアル酸, フコース 


\section{はじめに}

慢性副鼻腔炎，急性鼻炎，アレルギー性鼻炎などの多 くの鼻疾患では，鼻副鼻腔粘膜の分泌細胞からの分泌が 六進して抢り，鼻咽腔に運搬される分泌液量の増加は後 鼻漏として自覚される。特に慢性副鼻腔炎の粘膿性鼻汁 は正常状態で産生される分泌液より高い粘弾性を有して いるといわれ"，容易にきれることがないため患者にと って不快な症状となる。こうした病的気道液の組成につ いては，炎症やアレルギーなどの病態によって異なるこ とが示唆されており，なかでもフコース，シアル酸など の糖蛋白は気道の病態と密接に関連しているといわれて いるが233)，鼻汁については副鼻腔炎患者の鼻汁について

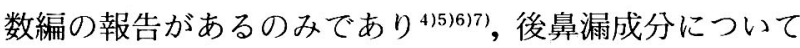
検討された報告はほとんどみられない。今回われわれは 後鼻漏, あるいは鼻腔後方の鼻汁（以下後鼻汁と略す） の化学成分を定量することにより, 若干の知見が得られ たので報告する。

\section{対象および方法}

対象は広島大学医学部耳鼻咽喉科で診察した 16 歳以 上の患者で，問診扔よび各種検査(自覚症状，他覚所見， $\mathrm{X}$ 線検査，鼻汁中好酸球検査，アレルゲン皮内反応検査， RAST)を行って，慢性副鼻腔炎と診断した 65 症例であ る。年噛は 16 歳 88 歳, 平均 59 歳, 男性 29 例, 女性 36 例であった。尚, 比較対照として急性副鼻腔炎 4 症例 の後方鼻汁を採取し検討を行った。慢性副鼻腔炎は，3 カ月以上の罹病期間を有するものとし, 治療開始前 2 週 間以内に急性増悪を認めた症例や手術的治療の既往のあ る症例は除外した。急性副鼻腔炎は罹病期間 2 週間以内 のものとした。また, 慢性副鼻腔炎症例で, 鼻汁好酸球, アレルゲン皮内反応検査，RAST のうち，2 種以上の検 査で陽性を示したものをアレルギー性鼻炎合併の慢性副 鼻腔炎症例（以下鼻ア合併例と略す）とし，アレルギー 性鼻炎を伴わない慢性副鼻腔炎症例は慢性副鼻腔炎単独 例（以下単独例と略寸）とした。対象症例 65 例のうち, 単独例 58 例, 鼻ア合併例 7 例であった。尚, 急性副鼻腔 炎症例はいずれもアレルギー性鼻炎を合併していない症 例である。

後鼻汁の採取は, 図 1 に示す吸引器を用いて中咽頭後 壁に認められる後鼻漏を直接口腔内より，また中咽頭に 後鼻漏が認められない場合は，前鼻汁を吸収しないよう に吸引の先端が鉤状突起を越えるまでは手元の吸引用の 穴を開放しておき，鈎状突起を過ぎたところで穴を閉じ て吸引を開始して鼻腔後方の鼻汁として採取した。後鼻
漏は厳密に言えば前述の中咽頭後壁に流下した鼻漏であ るが，このような後鼻漏を認め，以下に述べる各種成分 の測定が可能となる程の充分量を採取し得た症例数は少 なかったので，鼻腔後方より得られた鼻汁も加えて検討 した。従って真の意味の後鼻漏と鼻腔後方からの鼻汁を あわせて，本論文では後鼻汁と呼ぶことにさせて頂く。 採取した後鼻汁は，凍結保存後検榃に供した。

測定は，フコースに関しては Winzler のシステイン硫 酸法8)，シアル酸はイアトロ SA を用いた酵素法9)，エラ スターゼはSTANA 液，NEDA 液を用いた合成基質 法 $^{10)}$, アルブミンはラテックス凝集免疫測定法 ${ }^{11}$ をそれ ぞれ用い，実際の測定は特殊分析研究所に依頼して行っ た。また，治療による後方鼻斗の各成分の变化と治療効 果の関連性を検討する目的で, 慢性副鼻腔炎症例 12 例に ついて (単独例 8 例, 鼻ア合併例 4 例), 治療前後の後鼻 汁中のフコース，シアル酸，エラスターゼ，アルブミン を測定し，これらの測定值の変化と症状改善との関係を 検討した。

治療効果の判定には自覚症状と他覚所見に基づいてま ず著明改善, 改善, やや改善, 不変, 悪化の 5 段階に評 価し, 更にX線所見の効果判定も同じく著明改善, 改善, やや改善，不変，悪化の 5 段階に評価した(表 1 )。これ に基づいて, 自覚症状, 他覚所見による改善度を決定し (図 2)，次いでこれとX線所見とを組み合わせて総合改 善度を, 著明改善, 改善, やや改善, 不変, 悪化に評価 した(図 3 )。今回の評価では悪化した症例は 1 例もなか ったので, 改善以上を改善群, やや改善以下を不変群に 分け比較を行った。尚, 行った治療は単独例 8 例には工 リスロマイシン $600 \mathrm{mg}$ と S-carboxymetylcystein（S CMC) $1500 \mathrm{mg}$ 併用, 鼻ア合併例にはエリスロマイシン $600 \mathrm{mg}$ に抗アレルギー剂を併用投与した。投与期間は 8 週間とした。また，統計解析はWilcoxon 検定を用いた。

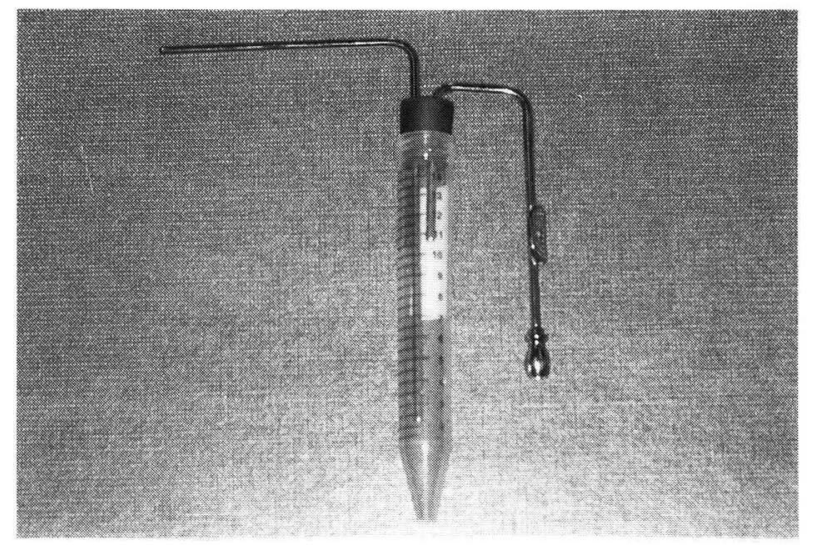

図 1 後鼻汁採取に使用した吸引器具 
結果

1) フコース值：慢性副鼻腔炎全症例 65 例の測定值は 33-33312 $\mu \mathrm{g} / \mathrm{ml}$ (中央值 $872 \mu \mathrm{g} / \mathrm{ml}$ ) であった。このうち, 単独例のフコース值は33-33312 $\mu \mathrm{g} / \mathrm{ml}$ (平均 $1771 \mu \mathrm{g}$ / $\mathrm{ml}$, 中央值 $835 \mu \mathrm{g} / \mathrm{ml})$ であり, 鼻ア合併例では 166 $2842 \mu \mathrm{g} / \mathrm{ml}$ (平均 $1241 \mu \mathrm{g} / \mathrm{ml}$, 中央值 $987 \mu \mathrm{g} / \mathrm{ml}$ ) であっ た。一方，急性副鼻腔炎のフコース值は，359-567 $\mu \mathrm{g} / \mathrm{ml}$ (平均 $459 \mu \mathrm{g} / \mathrm{ml}$, 中央值 $504 \mu \mathrm{g} / \mathrm{ml}$ ) であった。慢性副鼻 腔炎例のフコース値は, 急性副鼻腔炎のそれに比して高

表 1

自覚所見

(1)鼻をかむ頻度 (0:なし,1:2 3回/日,2:4 9回/日,3:常に)

(2)鼻のかみやすさ

(0:なし,1:すぐでる,2:強くかめば出る,

3:出ない)

(3)後鼻漏

(0:なし, 1:2 3回/日,2:時に,3:常に)

(4)後鼻漏の出しやすさ $(0:$ な $, 1:$ 出しやすい,2:出しにくい, 3:出すのが困難

（5)鼻閉（0:なし,1:気にならない,2:よくつまる,3:通らない）

(6)頭重,頭痛 (0:なし, 1:時々,2:度々,3:我慢できない)

(7)嗅覚障害(0:なし,1:少しわかる,2:やっとわかる,3:わからない) 他覚所見
(1)鼻粘膜発赤
(2)鼻粘膜浮腫
$(0:-, 1:+, 2:++, 3:+++)$
(0:-, 1 : 軽度, 2 : 中等度, 3 :高度)

(3)鼻汁量 $(0:-, 1:$ 中鼻道に少し,2:中鼻道に充満, 3:鼻腔に充満)

(4)鼻汁性状 (0:- 1 : 漿液性, 2:粘性, 3:粘膿性、朖性)

(5)後鼻漏 (0:-, 1:少しある,2: ある,3:層厚くある)

(6)後鼻漏の性状 $\quad(0:-, 1$ : 漿液性, 2 : 粘性, 3 : 粘膿性、膿性 $)$

\section{X線改善度}

(0:正常, 1 :軽度陰影, 2 :中等度陰影, 3 :高度陰影)

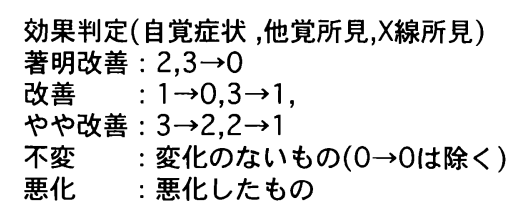

\begin{tabular}{|c|c|c|c|c|c|}
\hline 他 自 & 著明改善 & 改 善 & やや改善 & 不 変 & 悪 化 \\
\hline 著明改善 & & & & & \\
\hline 改 善 & & & & & \\
\hline やや改善 & & & & & \\
\hline 不 変 & & & & & \\
\hline 悪 化 & & & & & \\
\hline
\end{tabular}

著明改善 改善 軽度改善 $\square$ 不変 悪化 息：自覚症状

図 2 自覚症状，他覚所見による改善度の基準
い傾向にあったが，有意差は認められなかった。また， 単独例と鼻ア合併例の間にも有意差は認められなかっ た。平均值で比較すると小川らが報告した ${ }^{4)} 1410 \mu \mathrm{g} / \mathrm{ml}$ にほぼ近似した值であった。またこれは長岡2)の粘性痰 における $620 \mu \mathrm{g} / \mathrm{ml}$ に比し高い值であった（図 4 )。

2 ) シアル酸：慢性副鼻腔炎全症例 65 例の測定值は85$7094 \mu \mathrm{g} / \mathrm{ml}$ (中央值 $872 \mu \mathrm{g} / \mathrm{ml}$ ) であった。このうち, 単 独例のシアル酸值は85-7094 $\mu \mathrm{g} / \mathrm{ml}$ (平均 $1591 \mu \mathrm{g} / \mathrm{ml}$, 中 央值 $1168 \mu \mathrm{g} / \mathrm{ml})$ であり, 鼻ア合併例では625-1850 $\mu \mathrm{g} /$ $\mathrm{ml}$ (平均 $1068 \mu \mathrm{g} / \mathrm{ml}$, 中央值 $1032 \mu \mathrm{g} / \mathrm{ml}$ ) であった。一 方, 急性副鼻腔炎のシアル酸值は $1665-3914 \mu \mathrm{g} / \mathrm{ml}$ (平均 $2320 \mu \mathrm{g} / \mathrm{ml}$, 中央值 $1850 \mu \mathrm{g} / \mathrm{ml})$ であり, 急性副鼻腔炎 に比して慢性副鼻腔炎のシアル酸值が低い傾向を示した が有意差は認められなかった。しかしながら, 鼻ア合併 例のシアル酸值は, 急性副鼻腔炎に比べると有意に低い 值を示した。単独例ではKea1 ら ${ }^{12)}$ の慢性気管支炎の喀 痰の $750 \mu \mathrm{g} / \mathrm{ml}$ に比べると, 小川ら ${ }^{4)}$ の慢性副鼻腔炎鼻 汁の $1510 \mu \mathrm{g} / \mathrm{ml}$ とほぼ同様に高い值を示した（図 5 )。

3 ) シアル酸 $(\mathrm{S})$ のフコース (F) に対する比 $(\mathrm{S} / \mathrm{F}$ 比）: 慢性副鼻腔炎全症例 65 例の S/F 比は0.084-7.575 (中央值 1.455) で, 急性副鼻腔炎の3.16-6.90 (中央值 4.443)に比して低かったが, 有意差は認められなかった。 また, 慢性副鼻腔炎単独例と鼻ア合併例との間にも, 有 意差は認められなかった。しかし, 両者の值は急性副鼻 腔炎に比べるといずれも有意に低值であった（図 6 )。

4 ) エラスターゼ活性值：慢性副鼻腔炎全症例 65 例の 測定值は0.4-102.5 IU/1 (中央值 $8.2 \mathrm{IU} / 1$ ) であり,こ のうち単独例では0.4-102.5 IU/1 (平均 $17.0 \mathrm{IU} / 1$, 中央 值 $7.9 \mathrm{IU} / 1$ ), 鼻ア合併例では 1.52-95.5 IU/1 (平均 $34.0 \mathrm{IU} / 1$, 中央值 $30.6 \mathrm{IU} / 1)$ であった。一方急性副鼻腔 炎では28.2-205.4 IU/1 (平均 $124 \mathrm{IU} / 1$, 中央值 131.2 IU/1)であった。慢性副鼻腔炎全例のエラスターゼ

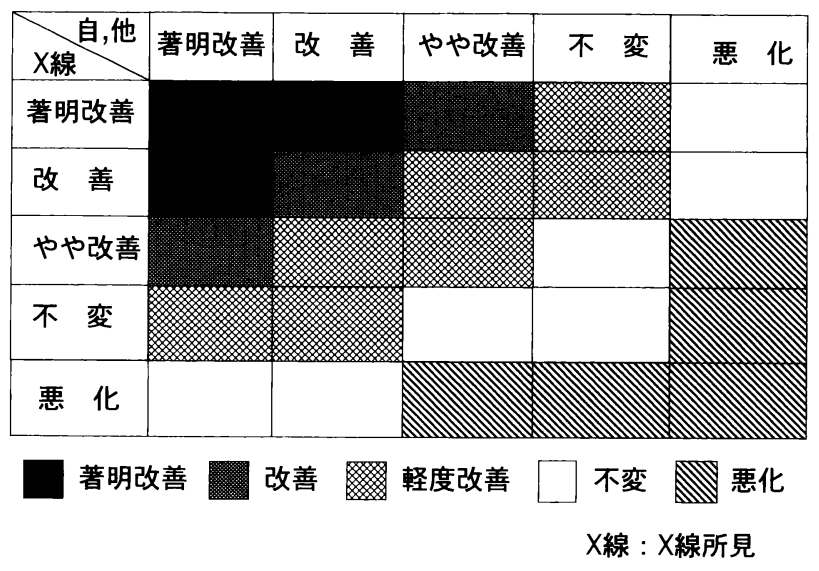

図 3 総合改善度判定基準 


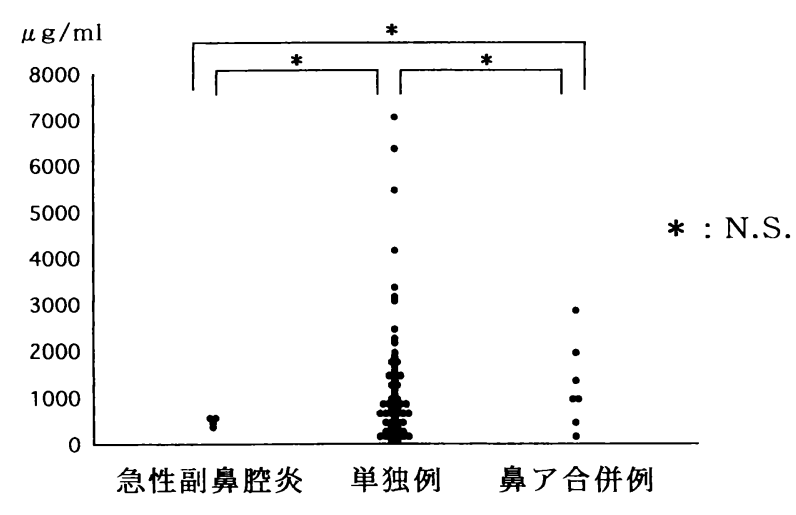

図 4 フコース濃度

值は急性副鼻腔炎に比して低値を示したが，有意差は認 められなかった。また，鼻ア合併例のエラスターゼ值と 急性副鼻腔炎のそれとの間にも有意差はみられなかっ た。しかしながら，単独例のエラスターゼ值は急性副鼻 腔炎に比して有意に低い值を示した（図 7 ）。

5 ）アルブミン值：慢性副鼻腔炎全症例 65 例の測定值 は，18-33900 $\mu \mathrm{g} / \mathrm{ml}$ (中央值 $1640 \mu \mathrm{g} / \mathrm{ml}$ ）であった。こ のうち, 単独例のアルブミン值は, $18-30400 \mu \mathrm{g} / \mathrm{ml}$ (平均 $4131 \mu \mathrm{g} / \mathrm{ml}$, 中央值 $1490 \mu \mathrm{g} / \mathrm{ml})$, 鼻ア合併例では320$33900 \mu \mathrm{g} / \mathrm{ml}$ (平均 $8049 \mu \mathrm{g} / \mathrm{ml}$, 中央值 $2486 \mu \mathrm{g} / \mathrm{ml}$ ) であ った。急性副鼻腔炎では3820-10400 $\mu \mathrm{g} / \mathrm{ml}$ (平均 $7298 \mu \mathrm{g}$ / $\mathrm{ml}$ ，中央值 $7485 \mu \mathrm{g} / \mathrm{ml}$ ) であった。これは慢性気管支炎 の粘性痰におけるアルブミン值について長岡 ${ }^{3)}$ が報告し ている $690 \pm 70 \mu \mathrm{g} / \mathrm{ml}$ に比較すると, 高い值であった。し かしながら全症例の慢性副鼻腔炎と急性副鼻腔炎症例の 間にも，慢性副鼻腔炎単独例と鼻ア合併例との間にも有 意差は認められなかった（図 8 )。

6 ）治療効果と各成分との関連性：単独例 8 例と鼻ア合 併例 4 例について前述の如く，エリスロマイシン $+\mathrm{S}-$ CMC，あるいはエリスロマイシン十抗アレルギー剤を投 与してその治療効果をみたところ, 単独例 8 例中改善し たもの 5 例，不変が 3 例であった。また，鼻ア合併例で は全例不変であった。単独例において, 治療前後のシア ル酸，フコースおよびその比である $\mathrm{S} / \mathrm{F}$ 比を検討したと ころ，症状改善群では治療によって，シアル酸の低下， フコースの上昇が認められ， $\mathrm{S} / \mathrm{F}$ 比の有意の低下が認め られた (図 9 )。しかし, 症状不変の 3 例では, このよう な傾向は認められなかった。また，鼻ア合併例に関して も治療前後のシアル酸，フコース， $\mathrm{S} / \mathrm{F}$ 比に一定の傾向 は認められなかった。エラスターゼは単独例症状改善群 で治療後に低下する傾向にあったが有意差はなく，アル ブミンについては治療前後で有意差はみられなかった。

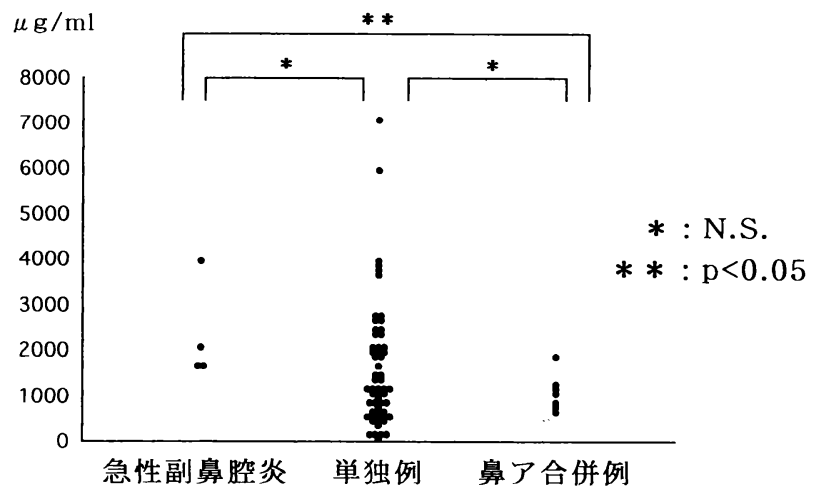

図 5 シアル酸濃度

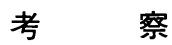

慢性副鼻腔炎の主症状の一つとして，以前より後鼻漏 が成書には記載されているが，その構成成分についての 記載はほとんどみられない。周知の如く，鼻・副鼻腔粘 膜上皮層は mucus blanketにより覆われているが，その 構成成分は $2 \sim 3 \%$ の複合糖質 (糖蛋白)，1〜2\%の無 機塩, 95〜 $97 \%$ の水分からなっている ${ }^{13)}$ 。このうち, 鼻 汁のレオロジーや粘弾性に大きな影響を与えているの は，ムチン型および血清型の 2 種類の糖蛋白である。こ れら糖蛋白の産生に関しては, 各種糖蛋白の糖鎖末端に 特異的に結合するレクチンを染色する免疫組織学的手法 による報告がある。これによれば，慢性副鼻腔炎粘膜の レクチン染色性は, wheat germ aggluitinine (WGA) の染色性は正常に比して低く，ulex eurepaeus agglutinine-1 (UEA-1) の染色性は中等度から高度に増

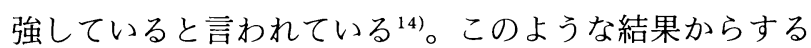
と, 慢性副鼻腔炎の鼻汁の組成でもシアル酸, マンノー スが少なく，フコースは多いことが推察されるが，鼻汁 中の糖蛋白の組成に関する研究は, 我々が涉猟し得た範 囲では小川等の報告など数編にみられるのみであ

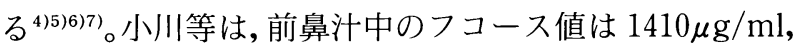
シアル酸值は $1510 \mu \mathrm{g} / \mathrm{ml}$ と報告しているが, その值が正 常人の鼻腔分泌液と比較して多いのか, 少ないのかなど については記載はない。その理由については記載はない が，正常人における鼻腔分泌液を採取するのはきわめて 困難であり，採取し得たとしても定量分析に充分な量を 手に入れることが困難なためと推察される。後鼻漏につ いては今までに報告がなく，今回我々はこの点に関して 測定を試みたが，同様の理由により正常人の鼻腔内分泌 液を採取し測定することが困難であったため，比較対照 として急性副鼻腔炎の後鼻汁を採取し検討を行った。ま た，慢性副鼻腔炎と診断した症例の中で実際に中咽頭に 


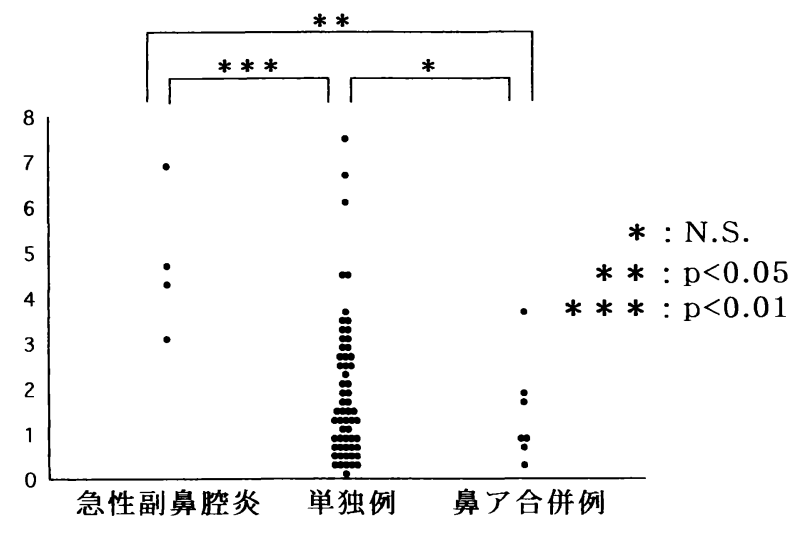

図 $6 \mathrm{~S} / \mathrm{F}$ 比

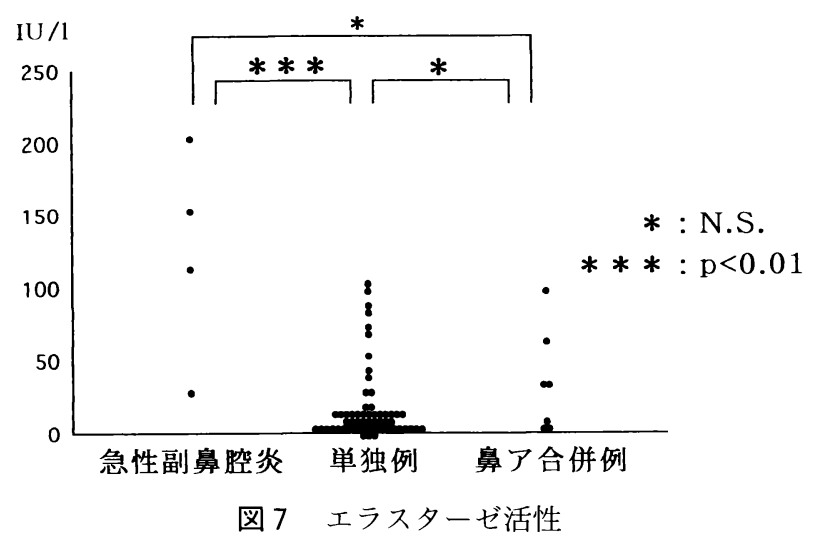

流下している後鼻漏を認めたのは約 $1 / 3$ であり,その他 は中咽頭に後鼻漏を認めることはできなかった。このた め, 前述した如く図 1 に示すような吸引装置を用いて鼻 腔中央部以後，すなわち鉤状突起部より後方に流下，停 滞している鼻汁をまず内視鏡にて確認した後に，前鼻汁 を吸引しないようにカテーテルの先端を鼻汁停留部の近 傍に近づけ,そこで吸引用の穴を閉鎖して鼻汁を採取し, これを後鼻漏の代替とした。

Winzler ${ }^{8)}$ が, 炎症および悪性腫瘍患者の血清中でフコ 一スとシアル酸の值が上昇することを報告して以来, こ れらと各種病態との関連について多くの研究がなされて いるが, 呼吸器疾患においても病態生理および臨床にか かわりが深いものとして重視されている。下気道疾患に 関して Roussel らは，喀痰中に認められるフコースにつ いて疾病状態のときにのみ出現するとしており ${ }^{15)}$, Keal らは, 慢性気管支炎患者の喀痰中のシアル酸含量が膿性 になるに従い，しかも冬期でより高くなることを報告し ている ${ }^{12)}$ 。また長岡は慢性気管支炎患者の喀痰中フコー ス濃度が気管支喘息患者の喀痰中フコース濃度に比べ有 意に高く, フコース濃度とシアル酸濃度の比率が線毛輸 送速度と関連すると報告している ${ }^{3)}$ 。鼻副鼻腔に関して は，斎藤は急性炎症でシアル酸が高いと報告している2。
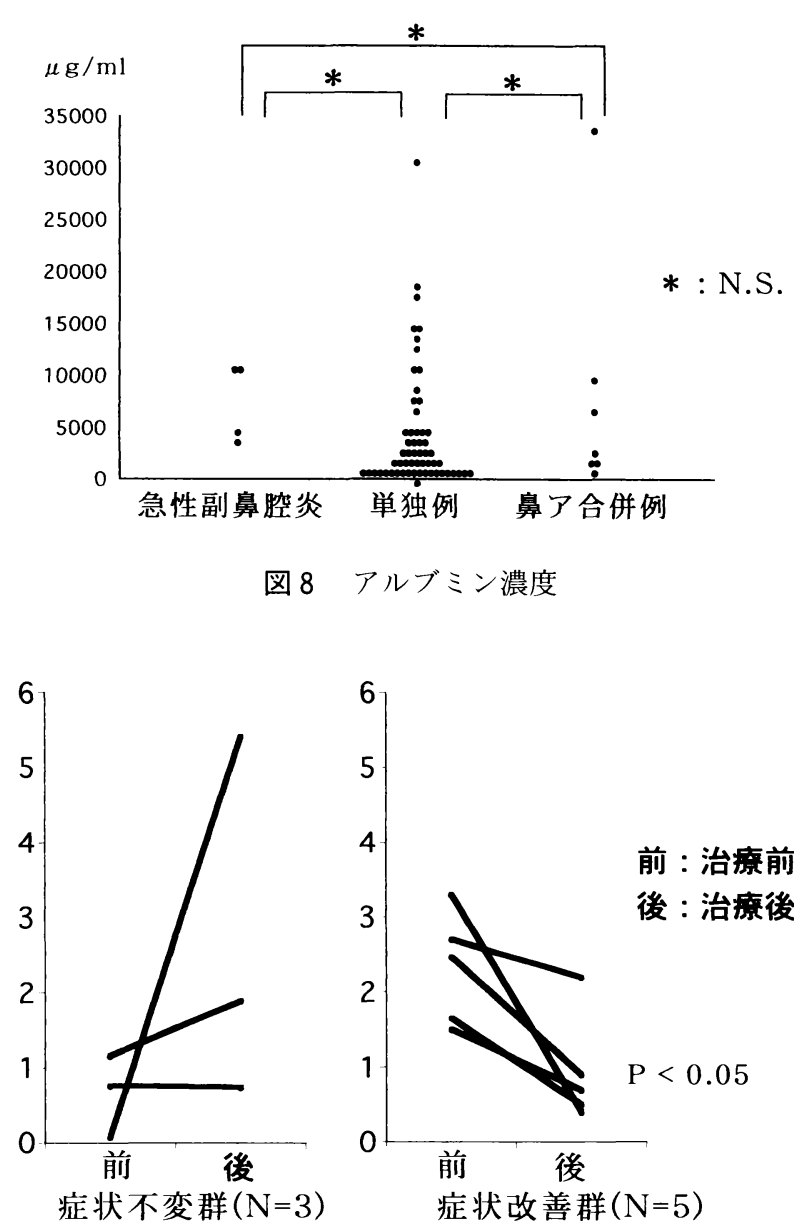

図 9 単独例における $\mathrm{S} / \mathrm{F}$ 比と治療効果

また血清中シアル酸は副鼻腔炎, 鼻アレルギー症例とも に正常者と有意差なく, フコース値は副鼻腔炎, 鼻アレ ルギー症例の順で有意に高値を示し, 副鼻腔炎鼻汁のシ アル酸やフコース值は鼻アレルギー鼻汁に比して有意に 高く, 喀痰における值よりも高值を示したとする小川ら の報告 ${ }^{4)}$ や WGA およびUEA-I レクチンを用いて喉頭 粘膜より正常下甲介粘膜の染色性が高いとした深水の報 告 ${ }^{16)}$, Tatsukawa らの副鼻腔炎粘膜での WGA による レクチン染色の報告 ${ }^{14)}$ などがあり，フコース，シアル酸 と副鼻腔炎の病態との関連性が強く示唆される。一方工 ラスターゼは好中球のライソゾーム顆粒に含まれる蛋白 分解酵素で, 膿性痰中に多数含まれる好中球から活性を 有するエラスターゼが遊離すると, 線毛上皮や基底膜な どを破壊し呼吸器組織に障害を与えることが予想され る3 。またアルブミンは喀痰において, 喀痰中に含まれる 蛋白のうち唯一血清由来のものとみなされており, 気管 支喘息患者の発作時の喀痰において有意に高く, 痰の曳 系性とアルブミン濃度との間には負の相関があると言わ れている3 。さらに喀痰中のアルブミン濃度の増加が糖 蛋白の分泌を増加させ，アルブミンと糖蛋白との相互作 
用によって線毛輸送されにくい濃厚な粘液が形成される 可能性が示唆されている ${ }^{3)}$ 。また浜口らは慢性副鼻腔炎 患者とアレルギー性鼻炎患者の鼻汁を採取し, 免疫グロ ブリン濃度とアルブミン濃度を測定し, 膿性鼻汁で血清 中アルブミンの漏出が著明に立進している可能性を示唆 している5 エラスターゼ, アルブミンについて今まで報告のない後 鼻汁で検討を行った。尚, ゾル層の主成分と考えられて いるマンノースについては, 鼻汁の採取量の問題により 測定を断念した。

今回のわれわれの結果を小川らの慢性副鼻腔炎鼻汁で の報告 ${ }^{4)}$ と対比させると, フコース, シアル酸の值はほぼ 同様であった。また例数は少ないものの急性副鼻腔炎で はシアル酸，エラスターゼ活性が高く， S/F 比は慢性副 鼻腔炎単独例, 鼻ア合併例に比して有意に高い值であり, 急性炎症でシアル酸が高いという斉藤の報告 ${ }^{2)}$ が反映さ れる結果であった。 $\mathrm{S} / \mathrm{F}$ 比については急性副鼻腔炎でシ アル酸濃度が高くフコース濃度が低いことが強調された 形となった。エラスターゼについては, 単独例に比較し て急性副鼻腔炎の方が有意に高かったが，これは急性副 鼻腔炎に膿性後鼻汁が多く，好中球優位であることを反 映しているものと考えられる。またアルブミン值は喀痰 における測定值よりも高く, 後鼻汁中への血清成分の漏 出が強いことが示唆された。しかしながら, 慢性副鼻腔 炎症例の中での測定值のばらつきが大きく, 各疾患群お よびアレルギーの有無による差は認められず, 充分な考 察を行い得る結果は得られなかった。このことは, 他の 項目についても考慮すべき反省点である。すなわち慢性 副鼻腔炎と診断した例の中でも, 炎症の時期や重症度に より後鼻汁の成分も当然変化することが予想されること である。尚, 今回は膿性, 粘性などの後鼻汁性状による 詳細な比較ができず，また重症度との関連について検討 できなかったため, 慢性副鼻腔炎の中での比較が不十分 であった。また鼻ア合併例についても, 採取時のアレル ギー症状の程度についての検討は行うことができず, こ れらの点が大きな反省点として残された。

一方, 治療による後鼻汁の成分の変化に関しては, 治 療前後に後鼻汁を採取し分析した報告はほとんどなく, 例数は少ないものの今回の我々の検討では興味のある結 果が得られた。すなわち慢性副鼻腔炎単独例の症状改善 群において S/F 比が有意に低下するが, 単独例および鼻 ア合併例の症状不変群においては $\mathrm{S} / \mathrm{F}$ 比の変化に特徵 的な所見がみられなかったことである。これに関しては, フコース濃度の高い鼻汁は高い粘弾性を示し, シアル酸 濃度対フコース濃度が高いと低い粘弾性を示したとする
平田らの報告 ${ }^{6)}$ や, 治療後の鼻汁の粘弾性は治療前に比 較して有意に低值を示したとする間島の報告 ${ }^{1)}$ がある。 今回のわれわれの検討では後鼻汁の粘弾性については検 討していないため, シアル酸やフコースと粘弾性との関 係について考察できないが, 単独群で治療に対する反応 性が良い症例では，ブコースやシアル酸の值にも影響が あり $\mathrm{S} / \mathrm{F}$ 比が低下する結果となり, 平田らや間島の報告 とは矛盾するものであった。この矛盾に関しては, フコ 一ス, シアル酸それぞれの作用が発揮される炎症の時期 や, 程度が測定時期によって異なっていることが予想さ れ，外来受診時には慢性副鼻腔炎と診断した症例でも， ある程度急性期あるいは急性増悪の像を併せ持つことも 考えられ，その場合にはシアル酸值が高く，経過により フコース值が上昇し, $\mathrm{S} / \mathrm{F}$ 比の低下がもたらされたこと も一因ではないかと考えられる。事実, 治療により症状 が変化しない症例では $\mathrm{S} / \mathrm{F}$ 比にも変動がなかったこと は，その一端を裏付けるものと考えている。しかしなが ら慢性副鼻腔炎が治癒に向かう際に, 結果として $\mathrm{S} / \mathrm{F}$ 比 の変動が生じたのか, $\mathrm{S} / \mathrm{F}$ 比の変動が治癒につながる指 標となっているのかについては未だ判然としていない。 また, 鼻ア合併例では $\mathrm{S} / \mathrm{F}$ 比は治療によっても変動がみ られなかったことも, 今後尚検討の余地があると考えて いる。今回の検討で, シアル酸が炎症の急性期に増加し ていることはほぼ明らかに言えるが, 慢性副鼻腔炎にお いてフコースが炎症のどの時期から増加し始めるか, 増 加したフコースは炎症の経過により実際に再度変動する ものか, などについて個々の症例の経過を追った分析は 行えなかった。また，エラスターゼやアルブミンの慢性 副鼻腔炎における意義についても, 現段階では明言でき る程のデー夕は得られなかった。慢性副鼻腔炎の中でも 炎症の時期や重症度によっても病態が異なるため, 今後 はこれらの点に考慮して個々の症例における各種成分の 推移を検討するとともに，マクロライド療法や酵素剤な どとの関連を主体に治療前後の後鼻漏成分の検討をすす めていく必要があると思われた。

\section{ま と め}

1. 副鼻腔炎患者の後鼻漏あるいは鼻腔後方鼻汁を採取 しそのフコース濃度, シアル酸濃度, エラスターゼ活性, アルブミン濃度の 4 つの成分について測定した。慢性副 鼻腔炎単独例のフコース值, シアル酸值は過去に報告さ れた慢性気管支炎の喀痰における值よりも高く, 慢性副 鼻腔炎鼻汁の值とほぼ同様の結果であった。

2. シアル酸は急性副鼻腔炎で高く鼻ア合併例との間に 統計学的有意差が認められた。 
3. $\mathrm{S} / \mathrm{F}$ 比は急性副鼻腔炎で高く, 単独例, 鼻ア合併例 で有意に低かった。

4. エラスターゼは, 急性副鼻腔炎と単独例との間に有 意差が認められた。

5 . 単独例の症状改善群では治療後の $\mathrm{S} / \mathrm{F}$ 比が有意に 低下していた。

慢性副鼻腔炎の治癒過程における $\mathrm{S} / \mathrm{F}$ 比の変動の意義 についてはさらに深く検討する必要性を痛感した。

本報告の要旨は第 36 回日本鼻科学会においてロ演し た。

\section{参考文献}

1) 間島雄一：鼻汁のレオロジー検査. 大山 勝編 : 耳 喉頭頝 MOOK. No1, 副鼻腔炎. 金原出版, 東 京, 1986, 89-95

2 ) 斎藤 等: 複合糖質との関係. 大山 勝編：耳喉頭 頝 MOOK. No1, 副鼻腔炎. 金原出版, 東京, $1986,44-50$

3 ) 長岡 滋：痰の化学的性状. 長岡 滋編：疾から何 が学びとれるか. ライフサイエンス出版, 東京, $1989,44-82$

4 ) 小川和昭, 伊東一則, 内㝨明裕, 他: 慢性副鼻腔 炎・鼻アレルギーにおけるシアル酸およびフコース に関する生化学的研究. 耳鼻臨床 $78 ： 2 ； 269-$ 276, 1985

5 ）浜口幸吉, 坂倉康夫, 間島雄一, 他：鼻疾患におけ る鼻汁中免疫グロブリン動態について. 耳鼻臨床 74 : 増 $2 ； 1170-1181,1981$

6 ）平田圭甫, 間島雄一, 坂倉康夫, 他：鼻汁の粘液糖 蛋白と粘弾性, Therapeutic Research vol. 11 no. 9 ; 328-331, 1990

7 ) 川本 智：鼻副鼻腔炎のムコ多糖に関する研究.耳 鼻臨床 $62 ： 7 ； 883-913,1969$
8 ) Winzler, R.J.: Methods of biochemical analysis. vol. 11 ; 294-296, 1955

9 ）谷内孝次, 宮本好信, 内田順博, 他：酵素法による シアル酸とその臨床応用. 臨床化学 7 ；403-410, 1979

10）片山幸一：合成基質を用いた elastase 活性測定法 の検討。医学のあゆみ.99：8；613-614，1976

11）石井周一, 和田守史, 山田俊幸, 他：LA システム （ラテックス比濁法）による尿中微量アルブミン測 定.日本臨床自動化学会会誌 $12 ： 2 ； 144-148$, 1987

12) Keal, E.E. and Lynne, R. : Neuraminic acid content of sputum in chronic bronchitis. Thorax 27 ; 643-653, 1981

13）市村恵一：鼻の病気：鼻の働き.SCOM. 金原出 版，東京，1994，13-21

14) Tatsukawa, T., Takeno, S., Hirata, S. etal: Glycoconjugates in human nasal epithelia with chronic sinusitis. XVIWorld Congress of Otorhinolaryngology Head and Neck Surgery. Sydney '97 International Proceedings; 16271629, 1997

15) Roussel, P., Degand, P., Lamblin, G. et al : Biochemical Definition of Human Tracheobronchial Mucus. Lung 154: 241-260, 1978

16）深水浩三：上気道粘膜における糖蛋白の組織化学的 研究. 日耳鼻 $88 ； 449-454,1985$

（1998 年 7 月 23 日，1999 年 1 月 30 日受理) 別刷請求先 $\boldsymbol{\top}$ 734-8551 広島市南区霞 1-2-3 広島大学医学部耳鼻咽喉科学教室

平田したう 